\title{
Transcriptional profile of Paracoccidioides spp. in response to itraconazole
}

\author{
Benedito Rodrigues da Silva Neto', Patrícia Fernanda Zambuzzi Carvalho ', Alexandre Melo Bailão', \\ Wellington Santos Martins ${ }^{2}$, Célia Maria de Almeida Soares ${ }^{1}$ and Maristela Pereira ${ }^{* *}$
}

\begin{abstract}
Background: Itraconazole is currently used to treat paracoccidioidomycosis. The mechanism of action of azoles has been elucidated in some fungi, although little is known regarding its mechanism of action in Paracoccidioides spp. The present work focused on identification of regulated transcripts using representational difference analysis of Paracoccidioides spp. yeast cells treated with itraconazole for 1 and $2 \mathrm{~h}$.

Results: Paracoccidioides Pb01 genes up-regulated by itraconazole included genes involved in cellular transport, metabolism/energy, transcription, cell rescue, defense and virulence. ERG11, ERG6, ERG3, ERG5 and ERG25 were up-regulated at multiple time points. In vivo infection experiments in mice corroborated the in vitro results. Ergosterol levels and distribution were evaluated in Paracoccidioides $P b 18$ yeast cells, and the results demonstrate that both factors were changed in the fungus treated with itraconazole.

Conclusion: To our knowledge, this is the first transcriptional analysis of Paracoccidioides spp. exposed to a triazole drug. Here acetyl seems to be intensively produced from different metabolic pathways to produce ergosterol by the action of ergosterol synthesis related enzymes, which were also affected in other fungi. Among the genes affected, we identified genes in common with other fungi, as well as genes unique to Paracoccidioides Pb01. Those genes could be considered target to new drugs. Voltage-gated $\mathrm{Ca}^{2+}$ alpha subunit (CAV), Tetracycline resistance protein (TETA) and Hemolisyn-iii channel protein (HLYiii) were found only here and a probably involvement with resistence to itraconazole could be investigated in the future. However our findings do not permit inference to current clinical practice.
\end{abstract}

Keywords: Paracoccidioides spp., Transcriptional response, Itraconazole, Ergosterol

\section{Background}

Paracoccidioides spp., a complex of several phylogenetic species, is the agent of paracoccidioidomycosis (PCM). Paracoccidioides spp. is a thermodimorphic fungus, which grows in the soil as saprobic mycelium, resulting in the formation of propagules, which initiate infection in humans when inhaled into the respiratory tract. Subsequently, in the lung, the mycelia propagules develop into yeast cells [1]. PCM is endemic in Latin America [2], with $80 \%$ of cases reported in Brazil, where it is the eighth-leading cause of mortality among infectious and parasitic diseases, establishing it as a serious public health problem $[3,4]$.

\footnotetext{
* Correspondence: maristelaufg@gmail.com

'Departamento de Bioquímica e Biologia Molecular, Laboratório de Biologia Molecular, Instituto de Ciências Biológicas, ICBII, Campus II, Universidade Federal de Goiás, C.P. 131, 74001-970 Goiânia, GO, Brazil

Full list of author information is available at the end of the article
}

Itraconazole is suggested to be the best alternative for first-line therapy of PCM and should be administered over a long period [5]. Itraconazole is a triazole antifungal drug, which are multi-ringed synthetic compounds containing three nitrogen atoms in the azole ring. Mechanistically, the triazole drugs inhibit the synthesis of ergosterol, an essential component of fungal cell membranes, and cause abnormalities in the membrane permeability and consequently cell death [6]. Itraconazole and related azole derivatives act by blocking the ergosterol biosynthesis pathway through the inhibition of the fungal cytochrome P450 enzyme lanosterol demethylase (Erg11) [7].

The global response to azoles, including itraconazole, of fungi such as Saccharomyces cerevisiae [8], Trichophyton rubrum [9], Aspergillus fumigatus [10] and Candida albicans [11,12] has been studied using transcriptional and proteomic approaches. In general, the findings revealed both specific and nonspecific antifungal-induced

\section{Biomed Central}


changes in gene and protein regulation. There was an increase in expression of the genes involved in lipid, fatty acid and sterol metabolism, as well as genes involved in drug adaptation, including cell stress response, drug efflux and small molecule transport.

Despite of the importance of Paracoccidioides spp., nothing is known about the mechanism of itraconazole inhibition in this pathogen. Here, cDNA libraries were constructed to obtain expressed sequence tags (ESTs) of Paracoccidioides spp. The representational difference analysis (RDA) technique was used to identify changes in the transcriptional profile of Paracoccidioides spp. in response to itraconazole, with the aim of identifying the adaptative response of the fungus to the compound. Transcript levels were also measured during the infection process. In addition, the transcript levels of ERG genes, ergosterol levels and ergosterol localization were evaluated.

\section{Results}

Libraries characteristics

A total of 861 ESTs were successfully sequenced. From these, 224 up- and 208 down-regulated ESTs were obtained from yeast cells after incubation with itraconazole for $1 \mathrm{~h}$, containing 55 singlets and 26 contigs for up-regulated transcripts and three singlets and 20 contigs for downregulated ones. In addition, 230 up- and 199 downregulated ESTs were obtained from yeast cells after incubation with itraconazole for $2 \mathrm{~h}$, containing three singlets and 10 contigs for up-regulated and seven singlets and 12 contigs for down-regulated. The ESTs obtained were submitted to the National Center for Biotechnology Information (NCBI) database under accession numbers: LIBEST_028165 Paracoccidioides Pb01 itraconazole $1 \mathrm{~h}$ up Library, LIBEST_028164 Paracoccidioides Pb01 itraconazole $1 \mathrm{~h}$ down Library, LIBEST_028167 Paracoccidioides Pb01 itraconazole $2 \mathrm{~h}$ up Library and LIBEST_028166 Paracoccidioides Pb01 itraconazole $2 \mathrm{~h}$ down Library.

The ESTs were processed using the Blast2GO program, which allowed us to annotate and identify the different functional groups. The functional classification was based on the homology of each EST, considering e-values $\leq 10^{-5}$ significant, using BLASTx against the GenBank non-redundant database and the MIPS functional annotation scheme (Table 1). The analyses indicated the presence of transcripts from different functional categories: metabolism/energy, transcription, cell rescue, defense and virulence, protein synthesis and biogenesis, protein fate, cellular transport, biogenesis of cellular components and cellular communication.

\section{Global gene expression monitoring in Paracoccidioides Pb01 upon itraconazole treatment}

A total of 86 genes were differentially expressed upon exposure to itraconazole, of which 55 were up-regulated and 31 were down-regulated. ESTs obtained from $1 \mathrm{~h}$ treatment with itraconazole were clustered into functional classes which were defined as metabolism/energy (26.12\%); transcription (17.09\%); cell rescue, defense and virulence (10.32\%); protein synthesis and biogenesis (2.90\%); protein fate $(2.90 \%)$; cellular transport $(23.87 \%)$; biogenesis of cellular components (1.61\%); cellular communication (1.29\%); and unclassified proteins (13.87\%). ESTs from $2 \mathrm{~h}$ samples were clustered into functional classes which were defined as: metabolism/energy (11.61\%); transcription (19.5\%); cell rescue, defense and virulence (20.74\%); protein synthesis and biogenesis $(0.82 \%)$; protein fate $(0.41 \%)$; cellular transport $(41.90 \%)$; and unclassified protein $(4.97 \%)$ (Figure 1).

It were found genes precursors of acety groups, from different metabolic pathways, such as acyl-CoA dehydrogenase $(A D H)$, isovaleryl-CoA dehydrogenase (IVD), pyruvate kinase $(P K)$ and cysteine desulfurase $(C Y S D)$.

In addition, genes precursors to the components of membrane and cell walls were found, such as phospholipids and carbohydrates, as well as genes related to detoxification. These components are diacylglycerol $o$-acyltransferase (DGAT), chitin synthase regulator $2(\mathrm{CHSr})$, hemolysiniii channel protein (HLYiii), tetracycline resistance protein (TETA), voltage-gated $\mathrm{Ca}^{2+}$ alpha subunit (CAV) and the MFS transporter.

\section{Expression profiles of genes in Paracoccidioides Pb01 yeast cells}

Confirmation of the expression levels of the ESTs found in the redundancy analysis was performed by qRT-PCR analysis, including Paracoccidioides Pb01 glutathione S-transferase (GST), (CHSr), betaine aldehyde dehydrogenase $(B A D H), C Y S D$, ribulose-phosphate 3-epimerase $(R P 3 E)$, carnitine/acyl-carnitine carrier (CAR), C6 transcription factor (CTFIB), $A D H$, heat shock protein (HSP30), GPR1/FUN34/YAAH family protein, PK, DGAT, IVD, ubiquitin-protein ligase $(U B I)$, family integral membrane protein (IMP), HSP10, HSP70 and ATP synthase f0 subunit 9 (ATPS9). These genes were chosen because of their high frequency or as representatives of different functional categories. Differential expression profiles of genes corroborated RDA data (Figure 2A).

\section{Analysis of ERG transcripts by qRT-PCR}

Because $E R G$ transcripts and proteins levels were changed in the presence of azoles in fungi such as T. rubrum [9], S. cerevisiae [8], C. albicans [11,12] and A. fumigatus [13] we investigated whether ergosterol synthesis-related transcripts such as lanosterol $14 \alpha$-demethylase (ERG11), C5, 6-desaturase (ERG3), delta-24-sterol C-methyltransferase (ERG6), C-22 sterol desaturase (ERG5) and C-4 methyl sterol oxidase (ERG25) were changed in Paracoccidioides Pb01 after $1 \mathrm{~h}, 2 \mathrm{~h}$ and $6 \mathrm{~h}$ of exposure to itraconazole 
Table 1 Genes differentially expressed in Paracoccidioides in response to treatment with itraconazole

\begin{tabular}{|c|c|c|c|c|c|}
\hline \multirow[t]{2}{*}{ Functional category } & \multirow[t]{2}{*}{ Gene product } & \multirow{2}{*}{$\begin{array}{c}\text { Best hit/Paracoccidioides } \\
\text { genome locus }\end{array}$} & \multirow[t]{2}{*}{ e-value } & \multicolumn{2}{|c|}{ Number of occurrences ${ }^{a}$} \\
\hline & & & & $1 \mathrm{~h}$ & $2 \mathrm{~h}$ \\
\hline \multirow[t]{19}{*}{ Metabolism/Energy } & 3-deoxy-7-phosphoheptulonate synthase (DAHP) & PAAG_03237 & $9.2 \mathrm{e}-29$ & +2 & \\
\hline & Cysteine desulfurase (CYSD) & PAAG_05850 & $2.2 e-58$ & +22 & \\
\hline & Betaine aldehyde dehydrogenase (BADH) & PAAG_05392 & $2.1 \mathrm{e}-19$ & +2 & \\
\hline & NADP-specific glutamate dehydrogenase $(G D H)$ & PAAG_07689 & $1.6 e-26$ & +1 & \\
\hline & NAD dependent epimerase dehydratase $(E D H)$ & PAAG_05580 & $1.6 e-30$ & +1 & \\
\hline & Succinyl 3-ketoacid-coenzime A transferase (SCOT) & PAAG_05093 & $2.6 \mathrm{e}-17$ & +1 & \\
\hline & Ribulose-phosphate 3-epimerase (RP3E) & PAAG_01632 & $6.5 e-42$ & -17 & \\
\hline & Aconitase $(A C O)$ & PAAG_05328 & $5.8 \mathrm{e}-18$ & -2 & \\
\hline & D-amino-acid oxidase (DAAO) & PAAG_02361 & $2.4 \mathrm{e}-38$ & -3 & \\
\hline & Er-associated proteolytic system protein (ERAD) & PAAG_04633 & $8.6 e-40$ & -4 & \\
\hline & Isovaleryl-CoA dehydrogenase (IVD) & PAAG_06830 & $1.0 e-23$ & +4 & \\
\hline & Acyl-CoA dehydrogenase $(A D H)$ & PAAG_05211 & $1.0 e-30$ & +1 & \\
\hline & Acyl-CoA dehydrogenase $(A D H)$ & PAAG_01222 & $2.1 \mathrm{e}-19$ & -8 & \\
\hline & Hormone-sensitive lipase (LIPE) & PAAG_06218 & $7.6 e-37$ & +1 & \\
\hline & Pyruvate kinase $(P K)$ & PAAG_06380 & $3.1 \mathrm{e}-31$ & +1 & \\
\hline & Aldehyde dehydrogenase (ALDH) & PAAG_05249 & $1.0 e-44$ & -4 & \\
\hline & Glutamine amidotranferase subunit pdxT (GLAT) & PAAG_07505 & $1.3 e-23$ & -5 & \\
\hline & ATP synthase f0 subunit 9 (ATPS9) & PAAG_12009 & $3.0 e-17$ & & +22 \\
\hline & Short chain dehydrogenase (DHS-14) & PAAG_04787 & $3.2 \mathrm{e}-48$ & +1 & \\
\hline \multirow[t]{8}{*}{ Transcription } & Transcription factor (STEA) & PAAG_00406 & $8.4 \mathrm{e}-50$ & +3 & \\
\hline & Isoform cra_b & PAAG_05467 & $3.2 \mathrm{e}-15$ & +1 & \\
\hline & Fator transcrição tipo $\mathrm{CCCH}$ & PAAG_02735 & $4.2 \mathrm{e}-27$ & +1 & \\
\hline & Pirin $(P I R)$ & PAAG_04726 & $2.5 e-52$ & +7 & +47 \\
\hline & RING finger protein (RNF) & PAAG_06129 & $1.5 e-18$ & +2 & \\
\hline & Apses transcription (APSES) & PAAG_02379 & $1.6 e-30$ & +1 & \\
\hline & mRNA-nucleus export ATPase & PAAG_04548 & $4.0 e-45$ & -27 & \\
\hline & C6 transcription factor (CTFIB) & PAAG_01359 & $4.5 e-65$ & -12 & \\
\hline \multicolumn{6}{|c|}{ Cell rescue, Defense and Virulence } \\
\hline & Survival factor1 (SVF1) & PAAG_02425 & $4.7 e-36$ & +1 & \\
\hline & Gluthatione S-transferase (GST) & PAAG_03931 & $1.0 e-33$ & +1 & \\
\hline & Vanadate resistence protein & PAAG_03940 & $9.4 \mathrm{e}-54$ & +2 & \\
\hline
\end{tabular}


Table 1 Genes differentially expressed in Paracoccidioides in response to treatment with itraconazole (Continued)

\begin{tabular}{|c|c|c|c|c|}
\hline Heat shock protein (STI1) & PAAG_06811 & $2.2 \mathrm{e}-24$ & +2 & \\
\hline Heat shock protein (HSP10) & PAAG_05142 & $6.5 e-32$ & +1 & +2 \\
\hline Heat shock protein (HSP3O) & PAAG_00871 & $5.4 e-52$ & -26 & -33 \\
\hline Heat shock protein (HSP70) & PAAG_08003 & $4.4 \mathrm{e}-40$ & & +3 \\
\hline Heat shock protein (HSP60) & PAAG_08059 & $4.3 e-55$ & & -12 \\
\hline \multicolumn{5}{|l|}{ Protein synthesis and biogenesis } \\
\hline ATP-dependent RNA helicase (ELF4A) & PAAG_00689 & $1.3 e-24$ & +7 & \\
\hline Serine threonine-protein kinase (SRK1) & PAAG_06726 & $7.6 e-66$ & -2 & \\
\hline 40 S ribosomal protein S4 (RPS4) & PAAG_03816 & $7.3 e-37$ & & +2 \\
\hline \multicolumn{5}{|l|}{ Protein fate (folding, modification, destination) } \\
\hline Ubiquitin-protein ligase (UBI) & PAAG_02632 & $3.7 e-11$ & +2 & \\
\hline WD repeat containing protein (WDR) & PAAG_00103 & $1.0 e-25$ & +1 & \\
\hline Ubiquitin thioesterase (OTU1) & PAAG_08841 & $1.0 \mathrm{e}-32$ & -5 & \\
\hline Ubiquitin fusion degradation protein (UFD) & PAAG_01475 & $1.0 \mathrm{e}-62$ & & +1 \\
\hline Proteasome component (PREP6) & PAAG_07802 & $6.1 e-5$ & +1 & \\
\hline \multicolumn{5}{|l|}{ Cellular transport, transport facilities and transport routes } \\
\hline Tetracycline resistance protein (TETA) & PAAG_01353 & $1.0 e-56$ & +13 & \\
\hline Mfs transporter (MFS) & PAAG_02191 & $7.3 e-56$ & +9 & \\
\hline Nucleoporin (SONB) & PAAG_02655 & $1.1 e-36$ & +1 & \\
\hline Voltage-gated $\mathrm{Ca}^{2+}$ alpha subunit (CAV) & PAAG_01353 & $9.9 e-15$ & +1 & \\
\hline Sodium-dependent phosphate transporter (SPIT) & PAAG_03892 & $1.5 \mathrm{e}-11$ & +1 & \\
\hline Zinc finger membrane protein $(\mathrm{DHHC})$ & PAAG_06616 & $6.6 e-53$ & -4 & \\
\hline autophagy regulatory protein & PAAG_04970 & $2.6 e-33$ & -2 & \\
\hline GPR1/FUN34/YAAH family protein & PAAG_08587 & $1.2 \mathrm{e}-47$ & -13 & -5 \\
\hline Carnitine/acyl carnitine carrier (CAR) & PAAG_03452 & $1.7 e-30$ & -18 & -89 \\
\hline General secretion pathway protein. & PAAG_05009 & $2.7 e-60$ & -10 & \\
\hline Family integral membrane protein (IMP) & PAAG_03183 & $4.1 \mathrm{e}-50$ & & +1 \\
\hline Hemolisyn-iii channel protein (HLYiii) & PAAG_01871 & $6.0 e-34$ & & +3 \\
\hline Integral membrane MPV17/PMP22 & PAAG_02868 & $6.6 e-37$ & & -2 \\
\hline Vesicular fusion protein (SEC17) & PAAG_06233 & $2.8 \mathrm{e}-77$ & & -1 \\
\hline \multicolumn{5}{|l|}{ Biogenesis of Cellular Components (cell wall/membrane) } \\
\hline Chitin synthase regulator 2 (CHSr) & PAAG_04860 & $2.0 \mathrm{e}-17$ & +3 & \\
\hline
\end{tabular}


Table 1 Genes differentially expressed in Paracoccidioides in response to treatment with itraconazole (Continued)

\begin{tabular}{|c|c|c|c|c|c|}
\hline & Oxysterol-binding protein (OSBP) & PAAG_06807 & $3.6 e-45$ & & +6 \\
\hline & Diacylglycerol o-acyltransferase (DGAT) & PAAG_07527 & $1.4 \mathrm{e}-64$ & +1 & \\
\hline & Phosphatidyl synthase (PHS) & PAAG_03571 & $6.5 e-34$ & +1 & \\
\hline \multicolumn{6}{|c|}{ Cellular communication/Signal transduction mechanism } \\
\hline & FluG Domain-containing protein & PAAG_05486 & $1.0 e-53$ & +1 & \\
\hline & Leucine -rich repeat Igi member $4(L G / 4)$ & PAAG_00833 & $1.0 e-25$ & +1 & \\
\hline & Conserved Lysine protein (LYS) & PAAG_03092 & $6.2 \mathrm{e}-43$ & +2 & \\
\hline \multirow[t]{20}{*}{ Unclassified protein } & Conserved hypothetical protein & PAAG_02735 & $1.3 e-39$ & +2 & \\
\hline & Conserved hypothetical protein & PAAG_01353 & $1.3 e-18$ & +6 & \\
\hline & Conserved hypothetical protein & PAAG_07364 & $5.8 \mathrm{e}-30$ & +4 & \\
\hline & Conserved hypothetical protein & PAAG_00520 & $3.9 e-27$ & +3 & \\
\hline & Conserved hypothetical protein & PAAG_02379 & $1.5 \mathrm{e}-19$ & +2 & \\
\hline & Conserved hypothetical protein & PAAG_02210 & $1.8 \mathrm{e}-37$ & +6 & \\
\hline & Conserved hypothetical protein & PAAG_02236 & $1.0 e-15$ & +1 & \\
\hline & Conserved hypothetical protein & PAAG_03559 & $4.8 e-47$ & +1 & \\
\hline & Conserved hypothetical protein & PAAG_03596 & $4.4 \mathrm{e}-83$ & +3 & \\
\hline & Conserved hypothetical protein & PAAG_08759 & $1.5 e-63$ & +2 & \\
\hline & Conserved hypothetical protein & PAAG_07907 & $1.0 \mathrm{e}-42$ & +2 & \\
\hline & Conserved hypothetical protein & PAAG_04000 & $1.0 \mathrm{e}-44$ & -4 & \\
\hline & Conserved hypothetical protein & PAAG_06816 & $1.7 e-8$ & & -2 \\
\hline & Conserved hypothetical protein & PABG_06807 & $1.0 e-51$ & & -6 \\
\hline & Conserved hypothetical protein & PAAG_01871 & $1.0 e-51$ & & -2 \\
\hline & Conserved hypothetical protein & PAAG_07034 & $3.4 \mathrm{e}-33$ & +2 & \\
\hline & Conserved hypothetical protein & PADG_04444 & $6.7 e-17$ & & +2 \\
\hline & Hypothetical protein & PAAG_02259 & $1.0 e-18$ & -3 & \\
\hline & Hypothetical protein & PAAG_02991 & $4.9 e-37$ & +1 & \\
\hline & Domain-containing protein (DUF1688) & PAAG_04000 & $7.5 e-17$ & +2 & \\
\hline
\end{tabular}

${ }^{a}$ Occurrences are expressed as the fold change relative to the value for the nontreated control; + , induction; -, repression. 


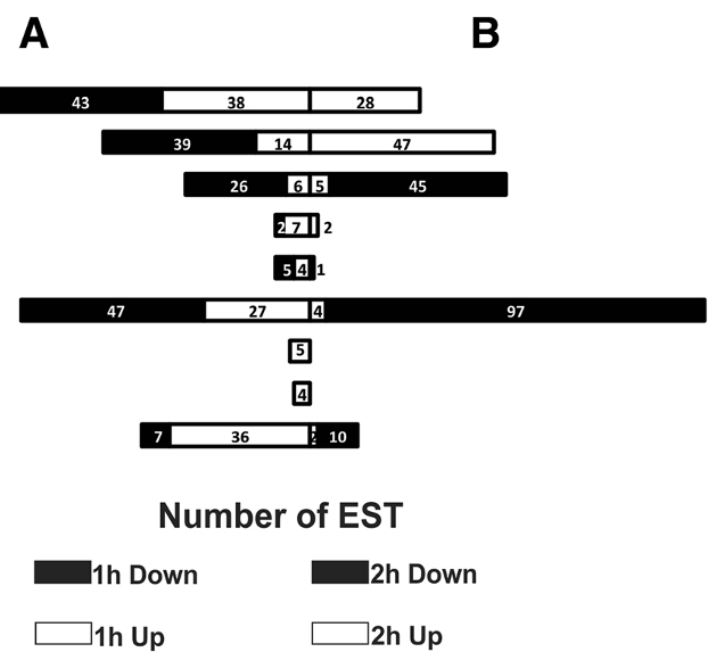

Figure 1 Functional classification of genes responding to itraconazole in Paracoccidioides. cDNAs obtained from RNAs from yeast cells after incubation with itraconazole for $1 \mathrm{~h}(\mathbf{A})$ and $2 \mathrm{~h}$ (B). The numbers of ESTs are indicated with white bar segments for the up-regulated genes and black bar segments for the down-regulated genes. The annotation of genes was performed using the Blast2GO program with a cut-off for significant homology of $\leq 1 \mathrm{e}^{-5}$. Sequences were grouped into functional categories according to their classification in the MIPS functional catalog. Additionally, sequences were grouped into functional categories using the PEDANT 3 database. Each functional class is represented as a segment and expressed as a number of ESTs in each library.

using specific oligonucleotides in qRT-PCR. The results showed that all transcripts were increased at all time points (Figure 2B).

\section{Paracoccidioides Pb18 transcripts identified in mice treated with itraconazole}

We investigated whether the regulated transcripts identified by RDA experiments using Pb01 also occurred in another cryptic species, $\mathrm{Pb} 18$, in vivo. Balb/c mice infected with Paracoccidioides $\mathrm{Pb} 18$ were treated with itraconazole, and spleens were removed. The treatment with itraconazole reduced the fungal burden $42 \%$ in the spleens. RNAs extracted from recovered fungus were analyzed in qRT-PCR experiments using MFS, GST and $\mathrm{CHSr}$ genes. In agreement with the RDA data, all the evaluated genes were up-regulated in spleen fungal samples after treatment with itraconazole (Figure 2C).

\section{GST-specific activity correlates with transcriptional data}

Because GST transcripts were up-regulated in our study and are described in the literature as important for the detoxification of many different xenobiotics [14], we evaluated the GST-specific activity in protein extracts of fungus grown in the presence of itraconazole. GST-specific activity in the presence of itraconazole $(0.26 \mu \mathrm{mol} / \mathrm{mg} /$ min) was 6.5 times higher than in the absence of itraconazole $(0.04 \mu \mathrm{mol} / \mathrm{mg} / \mathrm{min})$ (Figure $2 \mathrm{D})$.

\section{Analysis of the ergosterol level}

Because transcript levels of ergosterol pathway components were changed in the presence of itraconazole, we evaluated if itraconazole could disturb the total intracellular level of ergosterol. The method for quantification of ergosterol used here takes advantage of the unique four-peak spectral absorption pattern produced by extracted sterols between 240 and $300 \mathrm{~nm}$. Comparing the scans obtained from control (1.0 g of ergosterol/g yeast cells to Pb01; $1.2 \mathrm{~g}$ of ergosterol/g yeast cells to $\mathrm{Pb} 18$ ) and the corresponding itraconazole-exposed cultures ( $0.80 \mathrm{~g}$ of ergosterol/g yeast cells to $\mathrm{Pb01} ; 0.62 \mathrm{~g}$ of ergosterol/g yeast cells to $\mathrm{Pb} 18)$, a decrease of $39 \%$ and $48.6 \%$ was identified in the ergosterol content of Paracoccidioides $\mathrm{Pb} 01$ and $\mathrm{Pb} 18$ yeast cells, respectively grown in the presence of itraconazole.

\section{Effect of itraconazole on ergosterol localization in Paracoccidioides $P b 01$ and $P b 18$ yeast cells}

Because itraconazole induces changes in transcript levels in the ergosterol pathway and disturbs the total intracellular ergosterol content [15], the localization of ergosterol molecules was assessed in Paracoccidioides Pb01 and $\mathrm{Pb} 18$ yeast cells. Ergosterol was detected by its ability to bind to the dye filipin. This characteristic has been used to detect ergosterol in dimorphic fungi [16], yeasts, filamentous fungi $[17,18]$ and mammalian cells [19].

The distribution of ergosterol on the surface of Paracoccidioides $P b 01$ and $P b 18$ yeast cells treated with itraconazole was strikingly different from that observed in the control untreated cells. Control cells showed a homogeneous fluorescence distribution (Figure 3A and $\mathrm{C}$ ). In contrast, the cells treated with itraconazole displayed dark regions without filipin fluorescence (Figure 3B and D). 
A

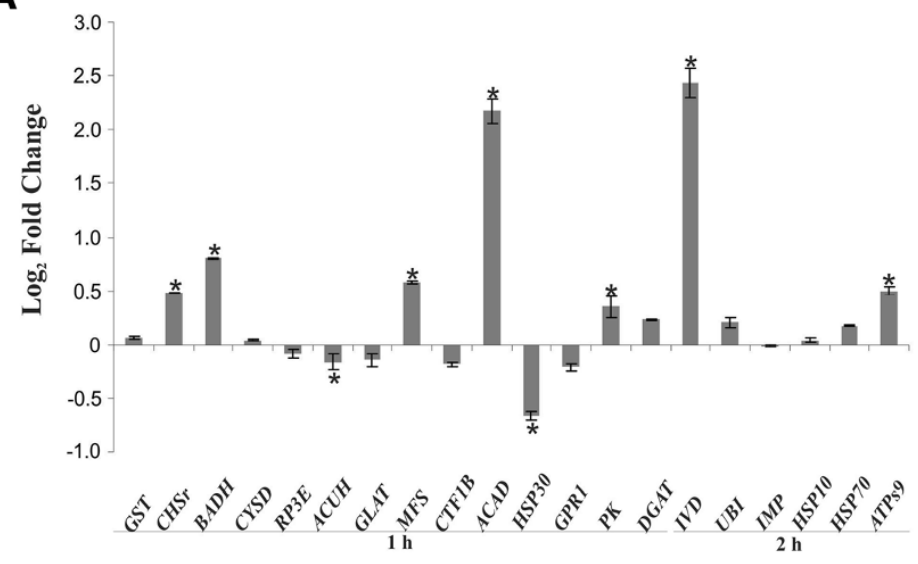

B

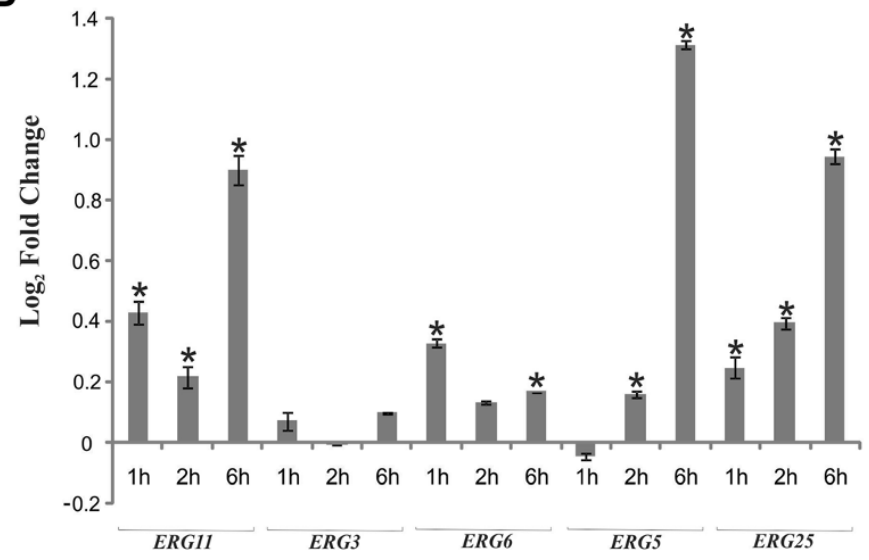

C
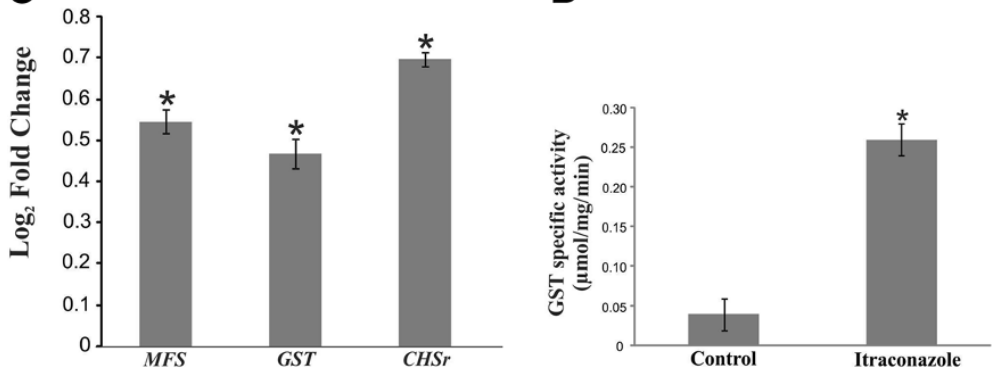

Figure 2 Relative fold change for genes determined by qRT-PCR. The gene expression profile for (A) twenty genes listed in Table 2, (B) the ergosterol pathway genes and (C) in vivo samples of Paracoccidioides recovered directly from systemically infected mouse spleens. Changes in gene expression levels were calculated by relative standard curve method using the control, untreated samples as the calibrator. (D) GST activity was measured in protein extract from Paracoccidioides Pb18 yeast cells grown in the presence or absence of itraconazole. Each error bar represents the standard error of the mean $( \pm \mathrm{SE})$ from three independent experiments performed in triplicate, and significant fold-changes are denoted by asterisks in the figure $\left({ }^{*} p \leq 0.05\right)$. Data were normalized to the transcript encoding the a-tubulin protein. Student's $t$ test was used for statistical comparisons.

A model for the Paracoccidioides spp. adaptation to the itraconazole

The most prominent adaptations undergone by Paracoccidioides spp. during exposure to itraconazole are summarized in Figure 4. See the Discussion for details.

\section{Discussion}

Among the Paracoccidioides $P b 01$ genes regulated by itraconazole were those involved in cellular transport, metabolism/energy, transcription, cell rescue, defense and virulence. Similar and different groups were also 

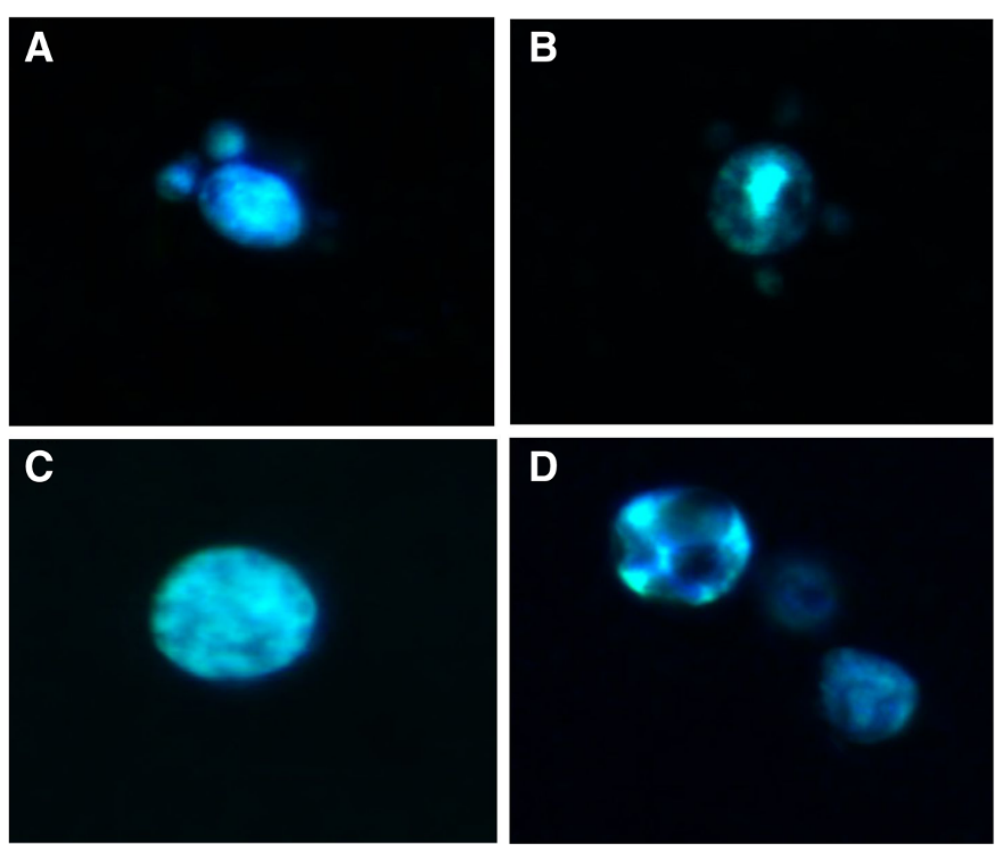

Figure 3 Sterol distribution in Paracoccidioides spp.. Yeast cells were fixed, stained with filipin and observed by fluorescence microscopy Staining in the control Pb01 (A) and Pb18 (C) cells was diffuse with homogeneous labeling. Pb01 (B) and Pb18 (D) cells treated with itraconazole displayed heterogeneous fluorescence.

observed in other fungi in response to different azoles $[8,9,11,12,15]$ (Figure 5). Among the genes affected, we identified genes in common with other fungi, as well as genes unique to Paracoccidioides. In fact few Paracoccidioides spp. genes were shared with genes from other fungi. This could be due to different techniques and classes of azoles used in the works. The comparison with ither fungi show that cell processes related to stress response, xenobiotic efflux are trigered upon itraconazol in different fungi. The genes exclusively regulated in Paracoccidioides spp. reveal that fungi response to drugs can partially involve specific processes that may be related to different sensibility of differetn fungi to itraconazol treatment. This could be due to different techniques and classes of azoles used in the works.

Although ERG genes were not identified in the RDA experiments, qRT-PCR results showed that ERG11, $E R G 3, E R G 6, E R G 5$ and ERG25 genes were temporally regulated, particularly after longer contact with the drug $(6 \mathrm{~h})$. Acetyl is a carbon donator in the cell production of ergosterol [8]. Acetyl CoA seems to be intensively produced due to up-regulation of transcripts from different metabolic pathways, including lipid degradation by hormone-sensitive lipase (LIPE) and ACAD and amino acid metabolism by $I V D$. Acetyl CoA pool increasing in the cell is optimized with reduction of aconitase trasncripts $(A C O)$, once this enzymes participates of the acetyl-CoA oxidation in TCA. In addition, the induction of $B A D H$ and $C Y S D$ could lead to production of thiamine, a cofactor to pyruvate dehydrogenase $(P D H)$, which produces acetyl CoA from pyruvate, whose production is increased by the action of pyruvate kinase (Figure 4).

Ergosterol is produced by the action of erg enzymes [20]. Here, the action of itraconazole on ergosterol biosynthesis and its distribution on Paracoccidioides Pb01 and $P b 18$ yeast cells surface was documented. Ergosterol is an essential component of fungal plasma membranes; it affects membrane permeability and the activities of membrane-bound enzymes. This sterol is a major component of secretory vesicles and has an important role in mitochondrial respiration and oxidative phosphorylation $[21,22]$. It can thus be expected that changes in ergosterol levels and in sterol structure could influence the activities of several metabolic pathways. The mechanism responsible for the global up-regulation of $E R G$ genes in response to azoles remains unclear. One theory postulates that depletion of ergosterol or another sterol formed late in the pathway increases global ERG expression; another argues that accumulation of an early substrate or toxic sterol by product induces ERG expression [23].

The correlation between cell wall integrity and perturbation of the ergosterol pathway in T. rubrun suggests that changes in the cell wall may compensate for stress in the plasma membrane [9]. The phospholipid level in the cell membrane seems to be affected in Paracoccidioides Pb01, as indicated by up-regulation of $D G A T$ and phosphatidyl synthase $(P H S)$, which produce phospholipids. DGAT has 


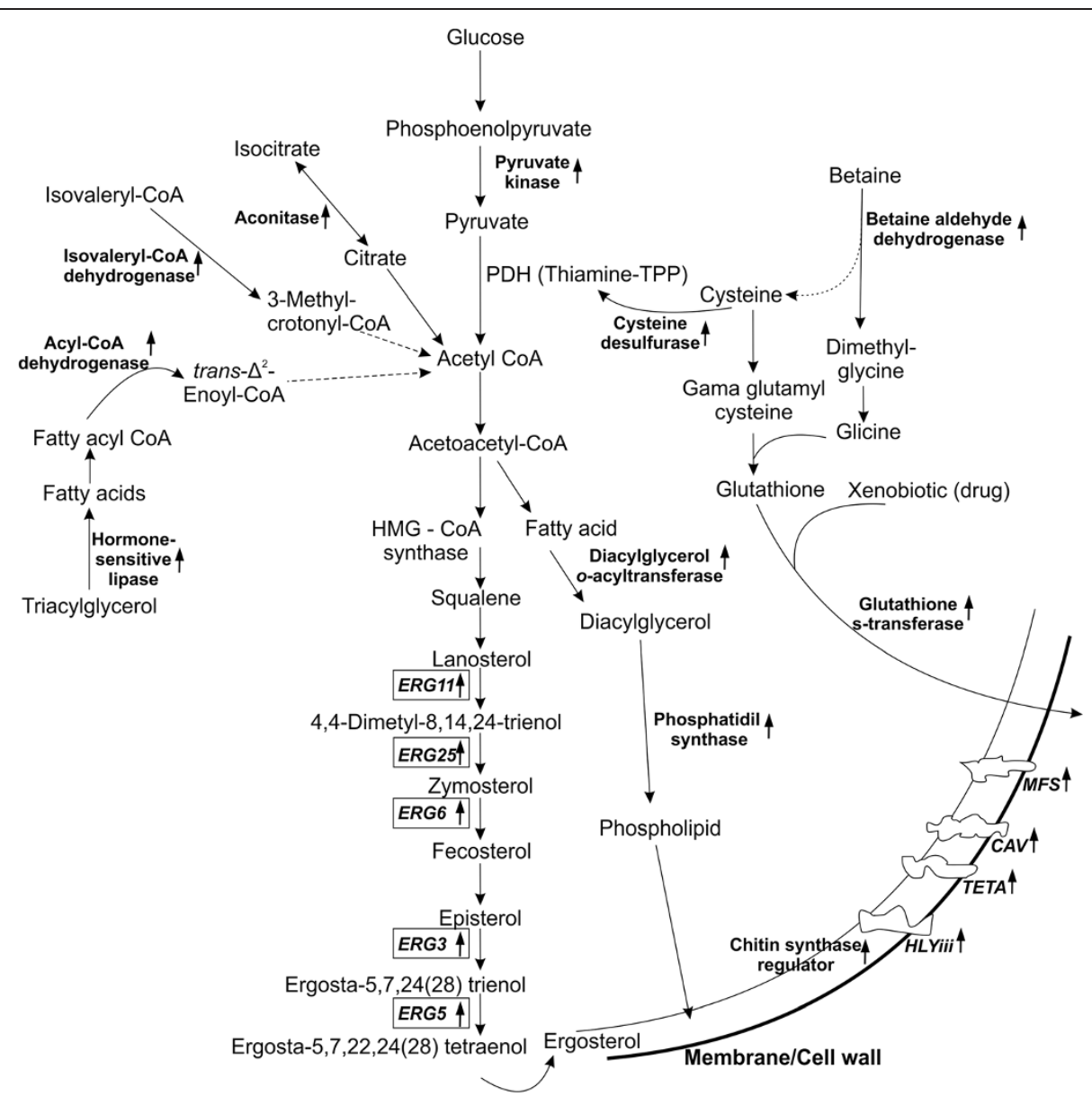

Figure 4 Hypothetical model for the mode of action of itraconazole against Paracoccidioides. The up-regulation of transcripts such as hormone-sensitive lipase, ADH, IVD and ACO from different metabolic pathways would produce acetyl CoA that would be used for ergosterol synthesis by ERG enzymes. Acetyl CoA would produce phospholipids for the membrane by the action of DGAT and PHS. The induction of BADH and CYSD would lead to production of thiamine, a cofactor of PDH, which would also produce acetyl COA. GST would conjugate glutathione to xenobiotics and would remove itraconazole from the cell using transporters, allowing for detoxification.

been found in several transcriptomes to date, indicating it may be important for the fungi response to azoles [15,24].

CHS and their regulatory genes are important for the growth and virulence of human fungal pathogens, including C. albicans $[25,26]$. It has been observed that high ergosterol levels can inhibit chitin synthases, whereas C. albicans mutants with low ergosterol content showed increased levels of chitin synthesis [27]. CHSr was upregulated in Paracoccidioides Pb01 in the presence of itraconazole.

Glutathione S-transferases, which are important for the detoxification of many xenobiotic compounds, are a family of multifunctional enzymes that play a role in cellular detoxification and excretion of a wide variety of xenobiotic substances [14]. It has been reported that Glutathione $\mathrm{S}$-transferases correlate with fungi defense in response to damage caused by oxidative stress, xenobiotics and antifungal compounds [28]. GST was up-regulated in Paracoccidioides in the presence of itraconazole.
In Paracoccidioides Pb01, genes encoding several classes of transporters were up-regulated upon exposure to itraconazole. MFS transporter and TETA, for example, have been implicated in azole resistance [29]. Drug resistance is often associated with the overexpression of genes encoding efflux pumps, which is presumed to prevent intracellular accumulation of itraconazole in fungus $[9,30]$. The up-regulation of Paracoccidioides Pb01 MFS, GST and CHSr transcripts also occur in vivo, as demonstrated here by qRT-PCR using RNAs extracted from spleens of mice.

It should be noted that a number of genes involved in small molecule transport, especially in ion transport, were differentially expressed in Paracoccidioides Pb01 in response to itraconazole. Up-regulated genes included $C A V, I M P$ and HLYiii. Down-regulated genes included (CAR) and integral membrane MPV17/PMP22. The inhibition of ergosterol, which is an essential component of fungal biological membranes, including the plasma 


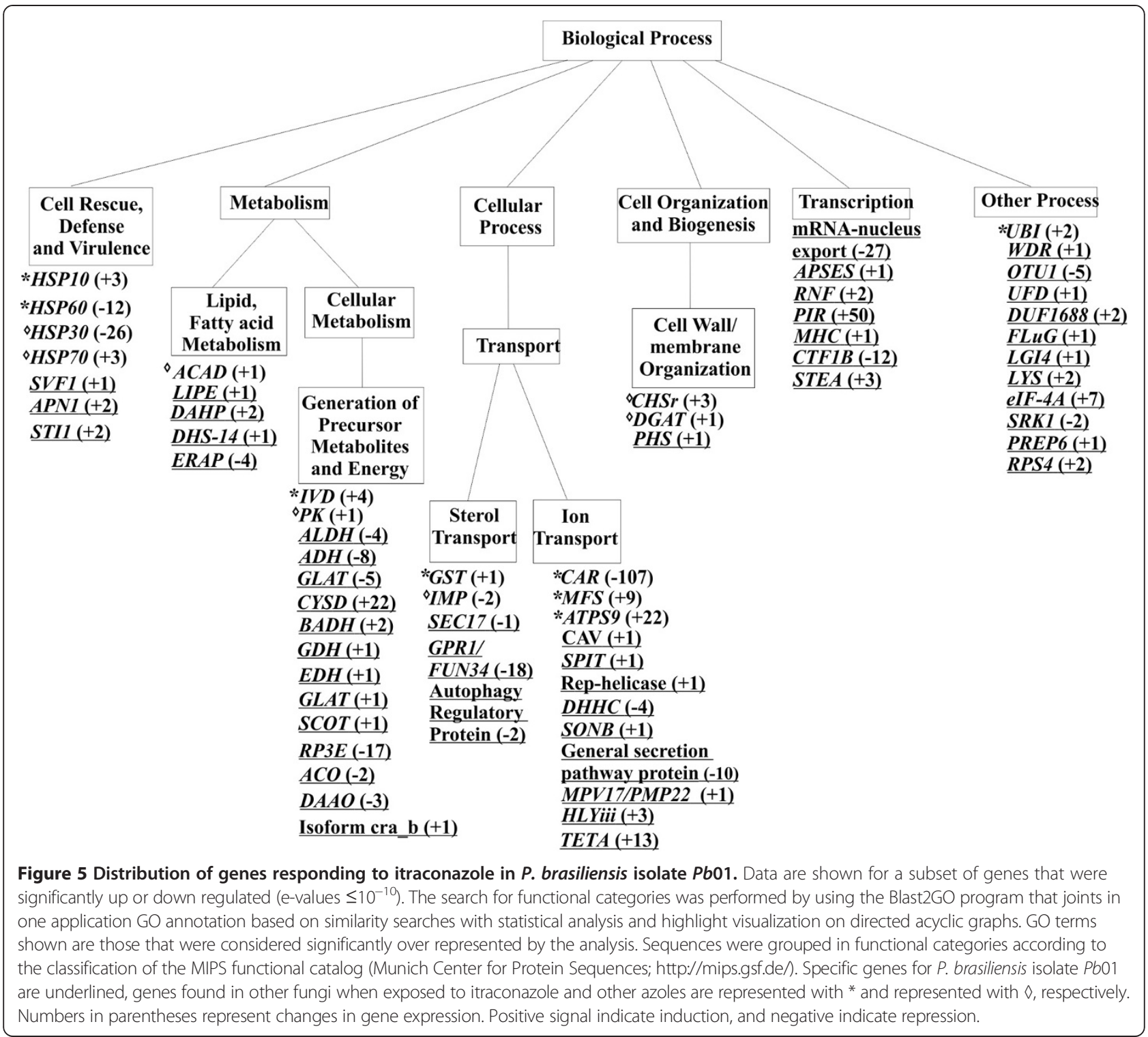

membrane, can lead to destabilization of the membrane, leakage of cellular components and influx of extracellular ingredients. Therefore, the regulation of transporter genes is necessary to maintain ionic homeostasis within the fungal cell when membranes are damaged by itraconazole $[9,31]$.

\section{Conclusion}

This is the first study to analyze the changes in the Paracoccidioides spp. gene expression profile following triazole exposure. Among the genes affected, we identified genes unique to Paracoccidioides Pb01, as well as genes in common with other fungi. In vitro results were validated by in vivo experiments. The results obtained here should assist in understanding the mode of action of itraconazole in Paracoccidioides spp.

\section{Methods}

\section{Culture and cell viability}

Paracoccidioides Pb01 and Pb18 have been studied at our laboratory previously [32,33]. $P b 01$ and $P b 18$ yeast phase was maintained in vitro by subculturing at $36^{\circ} \mathrm{C}$ in Fava Netto's semisolid medium [34] every seven days. Fava Netto's semisolid medium components were as follows: $1 \%(\mathrm{w} / \mathrm{v})$ peptone, $0.5 \%(\mathrm{w} / \mathrm{v})$ yeast extract, $0.3 \%$ $(\mathrm{w} / \mathrm{v})$ proteose peptone, $0.5 \%(\mathrm{w} / \mathrm{v})$ beef extract, $0.5 \%$ (w/v) $\mathrm{NaCl}, 4 \%(\mathrm{w} / \mathrm{v})$ glucose and 1.2\% (w/v) agar, $\mathrm{pH}$ 7.2. The determination of $\mathrm{IC}_{50}$ was performed according to Santos et al. [23] and in accordance with the macro dilution method described in the Clinical and Laboratory Standards Institute (CLSI) M27-A2(2005), with modifications. To determine the $\mathrm{IC}_{50}$, yeast cells in the exponential growth phase were maintained in the chemically defined 
solid medium McVeigh Morton (MMcM) [35], for seven days at $36^{\circ} \mathrm{C}$ and inoculated in liquid MMcM. A stock solution $(1 \mathrm{mg} / \mathrm{ml})$ containing sterile itraconazole (SigmaAldrich, St. Louis, MO, USA) was prepared in dimethylsulfoxide (DMSO). The final concentration of the solvent in the medium never exceeded $2 \%(\mathrm{v} / \mathrm{v})$ and had no effect on the cell growth. From this stock solution, the drug was serially diluted in sterile MMcM ( $\mathrm{pH} 7.0)$, producing a final concentration of $1.25-320 \mu \mathrm{g} / \mathrm{ml}(5-1260 \mathrm{mM})$. The drug concentration range was selected based on previous studies [36]. The controls without antifungal and DMSO were included. The concentrations of inoculums were determined by spectrophotometer using a yeast cell suspension in sterile $0.85 \% \mathrm{NaCl}$ with $10 \%$ transmittance at $520 \mathrm{~nm}$. The mixture was stirred to disperse aggregated cells. Yeast cells were collected from the liquid MMcM and counted in a Neubauer chamber. An initial inoculum containing $5 \times 10^{6}$ cells $/ \mathrm{ml}$ was collected, and $0.1 \mathrm{ml}$ aliquots were added to $2.4 \mathrm{ml}$ of MMcM containing the drug dilutions. The fungus was grown at $36^{\circ} \mathrm{C}$ under agitation at $150 \mathrm{rpm}$ for five days. The $\mathrm{IC}_{50}$ was determined using measurements of the turbidity of the medium [37]. The experiments were processed in triplicate.

For viability experiments, yeast cells were grown in the presence or absence of $4 \mu \mathrm{g} / \mathrm{ml}\left(\mathrm{IC}_{50}\right)$ of itraconazole and were kept in liquid MMcM [35] for 1, 2, 3, 4 and $5 \mathrm{~h}$ at $36^{\circ} \mathrm{C}$ before the viability of the cells was determined by Trypan Blue method [38]. In brief, cells from all incubation times were incubated with a dye solution (0.1\% Trypan Blue Stain) for 5 min at room temperature, and viability was assessed by counting viable and unviable cells in a Neubauer chamber.

\section{RDA: RNA extraction and CDNAs synthesis}

Paracoccidioides Pb01 yeast cells were cultured in MMcM broth medium in the presence or absence of $4 \mu \mathrm{g} / \mathrm{ml}$ of itraconazole for $1 \mathrm{~h}$ and $2 \mathrm{~h}$, corresponding to a viability of $95 \%$ and $85 \%$, respectively. For RNA isolation, cells were harvested by centrifugation, washed in cold water and the RNA from driver and tester cultures were extracted with Trizol (Invitrogen, Carlsbad, CA, USA) according to the manufacturer's instructions. RNA quality was assessed using the $A_{260 n m} / A_{280 n m}$ ratio. The RNA was treated with DNAse I RNAse-free (Invitrogen) to remove chromosomal DNA. The concentration and purity of RNA were determined by spectrophotometer, and RNA integrity was visualized after electrophoresis on $1.2 \%$ agarose gel. The RNAs were used to construct subtracted libraries and qRT-PCR experiments.

The cDNA fragments used for processing the RDA were generated according to the protocol previously described by Hubank and Schatz [39] and modified by Pastorian et al. [40]. Briefly, first-strand cDNA synthesis was performed with $1 \mu \mathrm{g}$ total RNA, obtained from driver and tester cultures, using SuperScript III reverse transcriptase (Invitrogen). The first-strand cDNA obtained ( $3 \mu \mathrm{l})$ was used as template to synthesize the second-strand of cDNA. The cDNA was prepared using the SMART PCR cDNA synthesis kit (Clonetech Laboratories, Palo Alto, CA, USA).

\section{RDA: Subtractive hybridization}

The cDNAs were digested with the restriction enzyme Sau3AI. Two successive rounds of subtraction employing different adapters (J-Bam and N-Bam, Table 2) were performed to enrich the differentially expressed sequences. Four cDNA-subtracted libraries were constructed. The cDNA libraries containing up-regulated genes were constructed from driver cDNA obtained from Paracoccidioides $\mathrm{Pb} 01$ yeast cells grown for $1 \mathrm{~h}$ and $2 \mathrm{~h}$ in MMcM medium and from tester cDNA, which was synthesized from RNA extracted from Paracoccidioides Pb01 yeast cells grown for $1 \mathrm{~h}$ and $2 \mathrm{~h}$ in MMcM medium plus itraconazole. The cDNA libraries containing down-regulated genes were constructed from driver cDNA, obtained from Paracoccidioides $P b 01$ yeast cells, grown for $1 \mathrm{~h}$ and $2 \mathrm{~h}$ in MMcM medium plus itraconazole and tester cDNA, which was synthesized from RNA extracted from Paracoccidioides Pb01 yeast cells grown for $1 \mathrm{~h}$ and $2 \mathrm{~h}$ in MMcM medium. The resulting products were purified using a GFX kit (GE Healthcare, Uppsala, Sweden). The tester-digested cDNA, from $1 \mathrm{~h}$ and $2 \mathrm{~h}$ samples, was linked to adapters (a 24-mer annealed to a 12-mer) and amplified by PCR.

For the generation of the differentially up- and downregulated products, the tester and driver cDNAs of both conditions were mixed separately; the hybridization occurred at $67^{\circ} \mathrm{C}$ for $18 \mathrm{~h}$ and the amplification occurred by PCR using the oligonucleotide matching the 24-mer adaptor [41]. The successive rounds of subtraction and amplification were performed using hybridization testerdriver ratios of 1:10 and 1:100. Adapters (Table 2) were changed between cross-hybridization, and the different products were purified using the GFX kit. After the second subtractive reaction, the cDNA was purified and cloned directly into the pGEM-T Easy vector (Promega, Madison, WI, USA). Escherichia coli XL1 Blue competent cells were transformed with the ligation products. The plasmid DNAs were prepared from selected clones of subtracted libraries and sequenced with the ET Dye Terminator kit Dyenamic (GE Healthcare) in a MegaBACE 1000 DNA sequencer (GE Healthcare) using primers corresponding to the pGEM-T Easy vector.

\section{Processing and annotation of ESTs}

The sequences of at least 75 nucleotides, with a PHRED score $\geq 20$ were considered for the assembly and formation of clusters. The assembly of these ESTs was performed 
Table 2 Oligonucleotide primers used in RDA assays and qRT-PCR

\begin{tabular}{|c|c|c|c|}
\hline Sequence name & Forward primer $\left(5^{\prime}-3^{\prime}\right)$ & Reverse primer $\left(5^{\prime}-3^{\prime}\right)$ & Amplicon size (bp) \\
\hline Glutathione S-transferase (GST) & GAACCGCAAACCCTAACCCT & ACAGCGGCTGAAAAGTCCCA & 157 \\
\hline Chitin synthase regulator $2(\mathrm{CHSr})$ & AGAGCTGCAGAATTAGGCCTT & TTTCGCCCGTTCATCTCCGT & 140 \\
\hline Betaine aldehyde dehydrogenase $(B A D H)$ & GTTGAAGAGCCATTTGGTCC & CAGATCATTGGACCACACAGA & 120 \\
\hline Cysteine desulfurase (CYSD) & CAACAGAAGAGATGGAGTATGA & AGCGAATGACACGTTGACACA & 143 \\
\hline Ribulose-phosphate 3-epimerase (RP3E) & CAATGGATCGACCTGATATGG & GACCTCCGTCAACTTCGATG & 141 \\
\hline Carnitine/acyl-carnitine carrier (CAR) & GAAGGCATTGCCAGGGGGT & CATTATGAACGGGGACGGTG & 139 \\
\hline Glutamine amidotransferase subunit pdxT (GLAT) & TGAGAGACTTTGTCAAGAACCA & TGCGCGGATAAATACACCCAT & 143 \\
\hline Mfs transporter (MFS) & CTAATTATGTTCTIITGGGGTAC & GCATCGCCTATACCAACAAGA & 136 \\
\hline C6 transcription factor (CTF1B) & CAAACCACTCGTCAACACAATC & GATTGCCTTGAGTCTGATAGAG & 138 \\
\hline Acyl-CoA dehydrogenase (ACAD) & GAGAACGAGACGCCCGAAG & GTTGTAGTAAGGACTCTTGTAG & 108 \\
\hline GPR1/FUN34/YAAH family protein & ACTGGCTGGGATGTGGGAG & TTCTTCTCCGTCATTTCCTTGA & 141 \\
\hline Pyruvate kinase $(P K)$ & ATGCGATGATAAATATCTCTACG & GACACTTGGCGCGGAGAGA & 143 \\
\hline Diacylglycerol o-acyltransferase (DGAT) & TATTAGATATACCAAGTGGCCG & TACCCTGGGTTTGTATTCAATG & 143 \\
\hline Isovaleryl-CoA dehydrogenase (IVD) & GATGTGGATTACCAACGGGC & TCATGCCAAGCTTGTCGAGTT & 152 \\
\hline Ubiquitin-protein ligase (UBI) & GGAGGCATGCAGATCTTCGT & ACGACCGTCCTCAAGCTGC & 168 \\
\hline Family integral membrane protein (IMP) & CGCCAGCAATCTGATTATCTC & AACCCAGCTGACCTTCATTAC & 142 \\
\hline Heat shock protein (HSP10) & TCTTCCTCCCAGAGAGCGC & CAGGGCTGCCTCCATACTG & 143 \\
\hline Heat shock protein (HSP3O) & GGCCTTGACAGCATTCTGG & CTGGCGATAAAGGGCAGAAG & 130 \\
\hline Heat shock protein (HSP70) & GCAGAAGGAGCTTGAAAGTGT & GTCAACCTCCTCGACAGTAG & 181 \\
\hline ATP synthase f0 subunit 9 (ATPS9) & AAGCAGCGAAAATAATGGGATC & GCAAATAATCCTGTAGCTTCTG & 181 \\
\hline Lanosterol 14 a-demethylase (ERG11) & CTGAGCTGTAGGGAAAAGTAC & TCCTCAGCGCAAACGTCCTT & 131 \\
\hline C5,6-desaturase (ERG3) & GGAGAATATGTATACCAGCCC & ATCCAAGTGATGAGATACAGAG & 128 \\
\hline Delta-24-sterol C-methyltransferase (ERG6) & GCTACTCTTACCCGACATTAC & AATGGGCAAGGTAATGTTCATG & 142 \\
\hline C-22 sterol desaturase (ERG5) & GGTCCCATGTTCAAAATCCCT & AAATTTGTGAAAACCGAGACG & 123 \\
\hline C-4 methyl sterol oxidase (ERG25) & GGACCATGGCCTACCAAATC & GCGGAGTATTGGTGGTGGAT & 129 \\
\hline $\mathrm{CDNA}^{*}$ & AGCAGTGGTATCAACGACAGAGTACGCGGG & & - \\
\hline $\mathrm{CDS}^{*}$ & AAGCAGTGGTATCAACGCAGAGTACT(30)N1N & & - \\
\hline PCRII* & AAGCAGTGGTATCAACGCAGAGT & & - \\
\hline JBam 12* & GATCCGTTCATG & & - \\
\hline JBam24* & ACCGACGTCGACTATCCATGAACG & & - \\
\hline NBam12* & GATCCTCCCTCG & & - \\
\hline NBam $24^{*}$ & AGGCAACTGTGCTATCCGAGGGAG & & - \\
\hline RBam12* & GATCCTCGGTGA & & - \\
\hline RBam24* & AGCACTCTCCAGCCTCTCACCGAG & & - \\
\hline $\mathrm{T} 7^{*}$ & GTAATACGACTCACTATAGGGC & & - \\
\hline Oligo $(\mathrm{dT})_{15^{*}}$ & AAGCAGTGGTATCAACGCAGAGTACT(30)N1N & & - \\
\hline
\end{tabular}

*Primers used in RDA experiments.

using CAP3 [42] and clustered to generate contigs and singlets, which were analyzed. All these tools were integrated in a specific pipeline (http://www.lbm.icb.ufg.br/pipelineUFG/). The annotation of genes was performed using the program Blast2GO (http://www.blast2go.org/), which provides a comparison between clusters of sequences obtained from public databases. The BLAST program from the National Center for Biotechnology Information (NCBI)
(http://www.ncbi.lm.nih.gov/BLAST), processed with the non-redundant sequences (nr) GenBank and the nucleotide database generated from Paracoccidioides spp. structural genome (http://www.broad.mit.edu/annotation/genome/pa racoccidioides_brasiliensis/MultiHome.html), was used for the annotation. The database sequence matches were considered significant at e-values $\leq 10^{-5}$. The program INTERPROSCAN (http://www.ebi.ac.uk/interpro/) [43] was used 
to obtain information about the domains present in clusters and the classification of families. The metabolic pathways were analyzed using maps obtained from the KEGG database (Kyoto Encyclopedia of Genes and Genomes) (http://www.genome.ad.jp/kegg) [44] with annotated EC numbers, and this information was used to help elucidate the function of ESTs. The Munich Information Center for Protein Sequences (MIPS) (http://mips.gsf.de/) was used to designate the functional categories. Additionally, sequences were grouped into functional categories using the PEDANT 3 database (http://pedant.helmholtz-muenchen.de/index.jsp).

\section{Analysis of RNA transcripts by qRT-PCR}

An aliquot of RNA from treated and untreated samples was used to perform reverse transcription qRT-PCR. Total RNAs from Paracoccidioides Pb01 yeast cells cultured in the presence or absence of itraconazole were obtained as previously described, in independent experiments from those used in the RDA assays. After treatment with DNAse, cDNAs were synthesized from total RNA using Superscript III reverse transcriptase (Invitrogen) and oligo $(\mathrm{dT})_{15}$ primer according to the supplier's instructions. Gene-specific primers were designed for the selected genes and for the control gene, $\alpha$-tubulin, using Primer Express software (Applied Biosystems, Foster City, CA, USA) (Table 2). qRT-PCRs were performed in triplicate in a StepOnePlus ${ }^{\mathrm{Tm}}$ real time PCR system (Applied Biosystems). The PCR thermal cycling program consisted of 40 cycles of $95^{\circ} \mathrm{C}$ for $15 \mathrm{sec} ; 60^{\circ} \mathrm{C}$ for $1 \mathrm{~min}$. The SYBR green PCR master mix (Applied Biosystems) was supplemented with 1 pmol of each gene-specific oligonucleotide and $40 \mathrm{ng}$ of template cDNA in a final volume of $20 \mu$ l. A curve melting analysis was performed to confirm the amplification of a single PCR product. The data were normalized to the $\alpha$-tubulin transcript amplified in each set of qRT-PCR experiments. A notemplate control was included. Samples of each cDNA were pooled and serially diluted 1:5 to generate a relative standard curve. Relative expression levels of genes were calculated using the standard curve method for relative quantification [45]. Statistical comparisons were performed using Student's $t$-test and samples with p-values $<0.05$ were considered statistically significant. The specific sense and antisense primers are listed in Table 2. Itraconazole-regulated transcripts were selected for qRT-PCR validation assays.

\section{Preparation of protein extracts and validation of data obtained by specific activity of Glutathione S-Transferase (GST)}

GST activity was measured with GST assay kit (SigmaAldrich). Briefly, the GST Assay Kit employs 1-Chloro-2, 4-dinitrobenzene (CDNB) to produce 1-glutathionyl-2,4- dinitrobenzene (GS-DNB) by conjugation of the thiol group of glutathione $(\mathrm{GSH})$. The reaction product GS-DNB absorbs at $340 \mathrm{~nm}$, and the rate of increase in the absorption is directly proportional to the GST activity of the sample.

Protein extracts from Paracoccidioides Pb18 yeast cells were prepared by inoculating $50 \mathrm{ml}$ of Fava Netto's liquid medium with $10^{6}$ cells $/ \mathrm{ml}$. Cultures were incubated overnight at $36^{\circ} \mathrm{C}$ with gentle shaking for $16 \mathrm{~h}$. Cells were centrifuged at 5,000 $\mathrm{g} g$ for $5 \mathrm{~min}$ and transferred into MMcM media containing itraconazole for $1 \mathrm{~h}$. Control cells were incubated in MMcM without drug. The cells were centrifuged at $10,000 \times g$ for $15 \mathrm{~min}$ at $4{ }^{\circ} \mathrm{C}$, frozen in liquid nitrogen and disrupted by maceration [46]. Extraction buffer $(20 \mathrm{mM}$ Tris- $\mathrm{HCl}$ pH 8.8; $2 \mathrm{mM} \mathrm{CaCl}_{2}$ ) containing a mixture of protease inhibitors (serine, cysteine and calpain inhibitors) (GE Healthcare) was added to the yeast cells. After the addition of glass beads $(0.45 \mathrm{~mm})$, the cells were lysed in a bead-beater, followed by centrifugation at $10,000 \times g$ for $15 \mathrm{~min}$ at $4^{\circ} \mathrm{C}$. The supernatant was collected, and the protein concentrations were determined using Bradford reagent (Sigma-Aldrich). The samples were stored in aliquots at $-80^{\circ} \mathrm{C}$.

The increase in absorbance is directly proportional to the GST activity. The GST-specific activity is defined as mmol of GS-DNB per $\mathrm{mg}$ of total protein per min $(\mathrm{mmol} / \mathrm{mg} / \mathrm{min})$. The enzymatic activity results represent the mean of three independent determinations, and statistical comparisons were performed using Student's $t$ test. The samples with $p$-values $\leq 0.05$ were considered statistically significant.

\section{Sterol quantification method}

The quantification of total intracellular ergosterol was performed as previously described [47], with slight modifications. Cell extracts from Paracoccidioides Pb01 and $\mathrm{Pb} 18$ yeast cells were prepared as already described above. Five $\mathrm{ml}$ of $25 \%$ alcoholic potassium hydroxide solution $(25 \mathrm{~g} \mathrm{KOH}$ and $35 \mathrm{ml}$ sterile distilled water added to $100 \mathrm{ml} 100 \%$ ethanol) was added to each tube, and the samples were mixed on a vortex for $2 \mathrm{~min}$. The cell suspensions were incubated in an $85^{\circ} \mathrm{C}$ water bath for $3 \mathrm{~h}$ and allowed to cool to room temperature. Sterols were extracted by addition of $2 \mathrm{ml}$ of sterile distilled water and $5 \mathrm{ml} n$-heptane (Sigma-Aldrich), followed by vigorous mixing in a vortex mixer for $5 \mathrm{~min}$. The samples were kept at room temperature for 1 to $2 \mathrm{~h}$ to allow the phases to separate or were stored at $4^{\circ} \mathrm{C}$ overnight. One $\mathrm{ml}$ of the heptane layer (containing ergosterol) was transferred to a $1.5 \mathrm{ml}$ quartz cuvette and analyzed spectrophotometrically by scanning at wavelengths between 200 and $300 \mathrm{~nm}$. If necessary, the samples were diluted five fold with $100 \%$ ethanol and reanalyzed. The ergosterol content as a percentage of the wet cell weight was 
calculated by the following equations: value $1=\left[\left(\mathrm{A}_{281.5} /\right.\right.$ $290) \times F] /$ wet cell weight, value $2=\left[\left(\mathrm{A}_{230} / 518\right) \times F\right] /$ wet cell weight, and percent ergosterol = value 1 - value $2 . F$ is the factor for dilution in ethanol, and 290 and 518 are fixed values determined for crystalline ergosterol and 24 (28) dihydroergosterol, respectively.

\section{Fluorescence microscopy}

Filipin stained samples were prepared using a previously described protocol for fixing and staining filamentous fungi [48]. Paracoccidioides Pb01 and Pb18 yeast cells were prepared by inoculating $50 \mathrm{ml}$ of Fava Netto's liquid medium with $10^{8}$ cells $/ \mathrm{ml}$. Cultures were incubated overnight at $36^{\circ} \mathrm{C}$ under gentle shaking for $16 \mathrm{~h}$. Cells were centrifuged at $5,000 \times g$ for $5 \mathrm{~min}$ and transferred in $\mathrm{MMcM}$ media containing itraconazole. Control cells were incubated in MMcM without drug. The fungus was then removed and fixed for $30 \mathrm{~min}$ in $3.7 \%$ formaldehyde and rinsed with $\mathrm{ddH}_{2} \mathrm{O}$. A $5 \mathrm{mg} / \mathrm{ml}$ stock solution of filipin (Sigma-Aldrich) dissolved in DMSO was diluted to $25 \mu \mathrm{g} / \mathrm{ml}$ and used to stain the fixed samples for 10 min. Samples were then rinsed with $\mathrm{dd}_{2} \mathrm{O}$, mounted on a microscope slide and sealed with nail varnish.

\section{BALB/c mice infection with Paracoccidioides $\mathrm{Pb} 18$}

The animals were bred at the Universidade Federal de Goiás animal facility under specific-pathogen-free conditions. All animal experiments were performed in accordance with the international rules for animal experimentation. The animal protocol was approved by the Universidade Federal de Goiás committee of the ethical treatment of animals (Number: 008/11 CEUA-UFG).

Female BALB/c mice, 8-12 weeks old, were inoculated with $1 \times 10^{7}$ of Paracoccidioides $\mathrm{Pb} 18$ yeast cells growth in liquid MMcM. In brief, yeast cell suspension in the 7 th day of in vitro growth were washed in PBS $1 \times$ and inoculated intraperitoneally in mice. The mice were divided into three groups of five animals to be sacrificed 21 days post-challenge. Each group was subdivided by treatment options as follows: five uninfected mice (negative controls), five yeast cell-infected mice (positive controls) and five yeast cell-infected mice treated with itraconazole starting at the third week post-infection. The animals were sacrificed in the sixth week after infection. The spleens were removed and homogenized in $5 \mathrm{ml}$ of sterile PBS $1 \mathrm{X}$. The homogenized sample was plated in brain heart infusion agar supplemented with $4 \%(\mathrm{v} / \mathrm{v})$ fetal calf serum and $2 \%(\mathrm{w} / \mathrm{v})$ glucose. The plates were incubated at $36^{\circ} \mathrm{C}$ and colony-forming units were determined after 20 days.

Gene expression analyses of Paracoccidioides Pb18 from infected mice were performed by isolating yeast cells from spleens as previously described with minor modifications [49]. The spleens of infected mice were homogenized in $1 \times$ PBS using a tissue grinder. The homogenate was then filtered using nylon mesh to remove large pieces of animal tissue. The sample was frozen in liquid nitrogen and then centrifuged at $500 \times g$ for 5 min to remove any remaining animal tissue. Next, the sample was centrifuged at 7,000 $\times g$ for $15 \mathrm{~min}$ to isolate fungal cells. Total RNA was extracted from recovered cells using TRIZOL reagent (Invitrogen), according to the manufacturer's instructions. RNA was used to perform qRT-PCR as described above.

\section{Competing interests}

The authors declare that they have no competing interests.

\section{Authors' contributions}

BRSN performed RNA extraction and Construction of CDNA libraries subtractive, annotation of ESTs, Analysis of RNA transcripts by qRT-PCR, Analysis of ERG transcripts by qRT-PCR, Preparation of protein extracts and specific activity of Glutathione S-Transferase (GST), Analysis of the ergosterol level, Fluorescence microscopy, and model for the Paracoccidioides spp. adaptation to the itraconazole. PFZC perfomed experiment sub-inhibitory concentration. WSM perfomed processing of ESTs. BRSN and AMB made BALB/C mice infection with Paracoccidioides Pb18. BRSN, AMB, CMAS and MP contributed to the discussion of the data and preparation of the manuscript. MP conceived, designed and coordinated the study. All authors contributed to the discussion of results. All the authors have read and approved the final manuscript.

\section{Acknowledgements}

This work performed at Universidade Federal de Goiás was supported by Ministério da Ciência e Tecnologia/Conselho Nacional de Desenvolvimento Científico e Tecnológico (MCTI/CNPq), Fundo Nacional de Desenvolvimento Científico e Tecnológico (FNDCT), Fundação de Amparo à Pesquisa do Estado de Goiás (FAPEG), Coordenação de Aperfeiçoamento de Pessoal de Nível Superior (CAPES), Financiadora de Estudos e Projetos (FINEP) and INCT_IF (Instituto Nacional de Ciência e Tecnologia para Inovação Farmacêutica). Additionally, B.R.S.N. was supported by a fellowship from CNPq and P.F.Z.C. by CAPES

\section{Author details}

${ }^{1}$ Departamento de Bioquímica e Biologia Molecular, Laboratório de Biologia Molecular, Instituto de Ciências Biológicas, ICBII, Campus II, Universidade Federal de Goiás, C.P. 131, 74001-970 Goiânia, GO, Brazil. ${ }^{~ I n s t i t u t o ~ d e ~}$ Informática, Universidade Federal de Goiás, Goiânia, Goiás, Brazil.

Received: 19 July 2013 Accepted: 26 March 2014

Published: 1 April 2014

\section{References}

1. Franco M: Host-parasite relationship in paracoccidioidomycosis. J Clin Microbiol 1987, 25:5-18.

2. Restrepo A, McEwen JG, Castañeda E: The habitat of Paracoccidiodes brasiliensis: how far from solving the ridle? Med Mycol 2001, 39:233-241.

3. San-Blas G, Niño-Vega G, Iturriaga T: Paracoccidioides brasiliensis and paracoccidioidomycosis: molecular approaches to morphogenesis, diagnosis, epidemiology, taxonomy and genetics. Med Mycol 2002, 40:225-242

4. Coutinho Z, Silva D, Lazera M, Oliveira RM, Sabroza PC, Wanke B: Paracoccidioidomycosis mortality in Brasil 1980-1995. Cad Saúde Pública 2002, 18:1441-1454

5. Shikanai-Yasuda MA, Telles FQ, Mendes RP, Colonbo AL, Moretti ML: Guidelines in paracoccidioidomycosis. Rev Soc Bras Med Trop 2006, 39:297-310

6. Burgess DS, Hastings RW: A comparison of dynamic characteristics of fluconazole, itraconazole, and amphotericin B against Cryptococcus neoformans using time-kill methodology. Diagnost Microbiol Infect Dis 2000, 38:87-93. 
7. Lamb DC, Maspahy S, Kelly DE, Manning NJ, Geber A, Bennett JE, Kelly SL: Purification, reconstitution, and inhibition ofcytochrome P-450 sterol, D22-desaturase from the pathogenic fungus Candida glabrata. Antimicrob Agents Chemother 1999, 43:1725-1728.

8. Bammert GF, Fostel JM: Genome-wide expression patterns in Saccharomyces cerevisiae: comparison of drug treatments and genetic alterations affecting biosynthesis of ergosterol. Antimicrob Agent Chemother 2000, 44:1255-1265.

9. Diao Y, Zhao R, Deng X, Leng W, Peng J, JIN Q: Transcriptional profiles of Trichophyton rubrum in response to itraconazole. Med Mycol 2009 47:237-247.

10. Georgiadou SP, Kontoyiannis DP: The impact of azole resistance on aspergillosis guidelines. Ann N Y Acad Sci 2012, 12721:5-22.

11. Liu TT, Lee REB, Barker KS, Lee RE, Wei L, Homayouni R, Rogers PD: Genome-wide expression profiling of the response to azole, polyene, echinocandin, and pyrimidine antifungal agents in Candida albicans. Antimicrob Agents Chemother 2005, 49:2226-2236.

12. Hoehamer CF, Cummings ED, Hilliard GM, Rogers PD: Changes in the proteome of Candida albicans in response to azole, polyene, and echinocandin antifungal agents. Antimicrob Agents Chemother 2010, 54:1655-1664

13. Georgiadou SP, Kontoyiannis DP: The impact of azole resistance on aspergillosis guidelines. Ann N Y Acad Sci 2012, 1272:15-22.

14. Hayes JD, Flanagan JU, Jowsey IR: Glutathione transferases. Annu Rev Pharmacol Toxicol 2005, 45:51-88.

15. De Backer MD, Ilyina T, Ma XJ, Vandoninck S, Luyten WH, Vanden Bossche $\mathrm{H}$ : Genomic profiling of the response of Candida albicans to itraconazole treatment using a DNA microarray. Antimicrob Agents Chemot 2001, 45:1660-1670.

16. Munkacsi AB, Pentchev PG, Sturley SL: Spreading the wealth: Niemann-Pick type $C$ proteins bind and transport cholesterol. Cell Metab 2009, 10:3-4

17. Breakspear A, Pasquali M, Brozc K, Donga Y, Kistler HC: Npc1 is involved in sterol trafficking in the filamentous fungus Fusarium graminearum. Fungal Genet Biol 2011, 48:725-730.

18. Van Leeuwen MR, Smant W, de Boer W, Dijksterhuis J: Filipin is a reliablein situ marker of ergosterol in the plasma membrane of germinating conidia (spores) of Penicillium discolor and stains intensively at the site of germ tubeformation. J Microbiol Method 2008, 74:64-73.

19. Beh $C T$, Rine J: A role for yeast oxysterol-binding protein homologs in endocytosis and in the maintenance of intracellular sterol-lipid distribution. J Cell Sci 2004, 117:2983-2996

20. Akins RA: An update on antifungal targets and mechanisms of resistance in Candida albicans. Med Mycol 2005, 43:285-318.

21. Vanden Bossche H, Marichal P, Gorrens J, Bellens D, Moereels H, Janssen PAJ: Mutation in cytochrome P450-dependent 14ademethylase results in decreased affinity for azole antifungals. Biochemic Soc Transact 1990, 18:56-59.

22. Daum G, Lees ND, Bard M, Dickson R: Biochemistry, cell biology and molecular biology of lipids of Saccharomyces cerevisiae. Yeast 1998, 14:1471-1510.

23. Santos GD, Ferri PH, Santos SC, Bao SN, Soares CMA, Pereira M: Oenothein $B$ inhibits the expression of PbFKS1 transcript and induces morphological changes in Paracoccidioides brasiliensis. Med Mycol 2007, 45:609-618.

24. Liu Q, Siloto RMP, Lehner R, Stone SJ, Weselake RJ: Acyl-CoA: diacylglycerol acyltransferase: molecular biology, biochemistry and biotechnology. Progr Lipid Resear 2012, 51:350-377.

25. Munro CA, Winter K, Buchan A, Henry K, Becker JM, Brown AJ, Bulawa CE, Gow NA: Chs1 of Candida albicans is an essentialchitin synthase required for synthesis of the septum and for cell integrity. Mol Microbiol 2001 39:1414-1426.

26. Banks IR, Specht CA, Donlin MJ, Gerik KJ, Levitz SM, Lodge JK: A chitin synthase and its regulator protein are critical for Chitosan production and growth of the fungal pathogen Cryptococcus neoformans. Eukaryot Cell 2005, 4:1902-1912.

27. Vanden Bossche $\mathrm{H}$ : Biochemical targets for antifungal azole derivatives hypothesis on the mode of action. Curr Top Med Mycol 1985, 1:313-351.

28. Wang W, Ballatori N: Endogenous glutathione conjugates: occurrence and biological functions. Pharmacol Rev 1998, 50:335-356.

29. Ghannoum MA, Rice LB: Antifungal agents: mode of action, mechanisms of resistance, and correlation of these mechanisms with bacterial resistance. Clin Microbiol Rev 1999, 12:501-517.
30. Lupetti A, Danesi R, Campa M, Del Tacca M, Kelly S: Molecular basis of resistance to azole antifungals. Trend Mol Med 2002, 8:76-81.

31. Edlind T, Smith L, Henry K, Katiyar S, Nickels J: Antifungal activity in Saccharomyces cerevisiae is modulated by calcium signaling. Mol Microbiol 2002, 46:257-268.

32. Da Silva Cruz AH, Brock M, Zambuzzi-Carvalho PF, Santos-Silva LK, Troian RF, Goes AM, Soares CMA, Pereira M: Phosphorylation is the major mechanism regulating isocitrate lyase activity in Paracoccidioides brasiliensis yeast cells. FEBS J 2011, 278:2318-2332

33. De Oliveira KM, Neto BRS, Parente JA, Da Silva RA, Quintino GO, Voltan AR, Mendes-Giannini MJ, Soares CMA, Pereira M: Intermolecular interactions of the malate synthase of Paracoccidioides spp. BMC Microbiol 2013, 13:107.

34. Fava Netto C, Vegas VS, Sciannamea JJ, Guarnieri DB: Antígeno polissacarídeo do Paracoccidioides brasiliensis. Estudo do tempo de cultura do P.brasiliensis necessário ao preparo do antigen. Rev Inst Med Trop 1969, 11:177-181.

35. Restrepo A, Jimenez BE: Growth of Paracoccidioides brasiliensis yeast phase in a chemically defined culture medium. J Clin Microbiol 1980, 12:279-281.

36. Hahn RC, Conceição YTM, Santos NL, Ferreira JF, Hamdan JS: Disseminated paracoccidioidomycosis: correlation between clinical and in vitro resistance to ketoconazole and trimethoprim sulphamethoxazole. Mycoses 2003, 46:342-347.

37. Hahn RC, Hamdan JS: In vitro susceptibilities of Paracoccidioides brasiliensis yeast form to antifungal drugs. Mycoses 2000, 43:403-407.

38. Freshney R: Culture of Animal Cells: A Manual of Basic Technique. New York: Alan R Liss; 1987. Inc.

39. Hubank M, Schatz AG: Identifying differences in mRNA expression by representational difference analysis of cDNA. Nucleis Acids Res 1994, 22:5640.

40. Pastorian $\mathrm{K}$, Havell $\mathrm{L}$ 3rd, Byus CV: Optimization of cDNA representational difference analysis for the identification of differentially expressed mRNAs. Anal Biochem 2000, 283:89-98.

41. Dutra $V$, Nakazato $L$, Broetto IS, Vainstein MH, Schrank A: Application of representational difference analysis to identify sequence tags expressed by Metarhizium anisopliae during the infection process of the Boophilus microplus cuticle. Res Microbiol 2004, 155:245-251.

42. Huang $X$, Madan A: CAP3: a DNA sequence assembly program. Genom Res 1999, 9:868-877

43. Apweiler R, Bairoch A, Wu CH: Protein sequence databases. Curr Opin Chem Biol 2004, 8:76-80.

44. Kanehisa M, Goto S: KEGG: Kyoto encyclopedia of genes and genomes. Nucleic Acids Res 2000, 28:27-30.

45. Kramer MF: High-throughput real-time quantitative reverse transcription PCR. In Current Protocols in Molecular Biology. Edited by Ausubel FM, Brent R, Kingston RE, Moore DD, Seidman JG, Smith JA, Struhl K. Hoboken NJ: John Wiley and Sons; 2006:1581e1628.

46. Fonseca CA, Jesuino RS, Felipe MS, Cunha DA, Brito WA, Soares CMA: Two-dimensional electrophoresis andcharacterization of antigens from Paracoccidioides brasiliensis. Microb Infect 2001, 3:535-542.

47. Arthington-Skaggs BA, Jradi H, Desai T, Morrison CJ: Quantitation of ergosterol content: novel method for determination of fluconazole susceptibility of Candida albicans. J Clin Microbiol 1999, 37:3332-3337.

48. Momany M: Using microscopy to explore the duplication cycle. In The Molecular and Cellular Biology of Filamentous Fungi: A Practical Approach. Edited by Talbot N. Oxford: University Press; 2001. Oxford.

49. Andes D, Lepak A, Pitula A, Marchillo K, Clark J: A simple approach forestimating gene expression in Candida albicans directly from a systemic infectionsite. J Infect Dis 2005, 192:893-900.

doi:10.1186/1471-2164-15-254

Cite this article as: Neto et al:: Transcriptional profile of Paracoccidioides spp. in response to itraconazole. BMC Genomics 2014 15:254. 